\title{
Assessment of renal dysfunction in workers previously exposed to mercury vapour at a chloralkali plant
}

\author{
Dag G Ellingsen, Lars Barregård, Per I Gaarder, Björn Hultberg, Helge Kjuus
}

\begin{abstract}
Urinary albumin concentration (U-alb) and $N$-acetyl- $\beta$-D-glucosaminidase (U-NAG) and glomerular basement membrane antibodies (a-GBMs) in serum samples were measured in 77 chloralkali workers previously exposed to mercury $(\mathrm{Hg})$ vapour and 53 age matched referents. The exposure ceased on average $12 \cdot 3$ (range 1-35) years before the study. The mean exposure time was 7.9 (range $1 \cdot 1-36 \cdot 2$ ) years. The mean yearly urinary $\mathrm{Hg}$ concentration (U-Hg) was $531 \mathrm{nmol} / \mathrm{l}$. The concentrations of the urinary isoenzymes NAG A (U-NAG A) and NAG B (U-NAG B) were determined in 30 highly exposed subjects and 30 referents. No differences in U-alb or U-NAG, U-NAG A, or U-NAG $B$ were found between the groups. Higher concentrations of a-GBMs were found among subjects who stopped exposure a short time before the study, but there was no association between a-GBMs and $U$-alb. The $U-$ NAG and U-NAG $A$ were negatively correlated with storage time. The results may suggest that microalbuminuria and enzymuria reported in subjects with ongoing exposure to $\mathrm{Hg}$ vapour are reversible in most instances.
\end{abstract}

(British fournal of Industrial Medicine 1993;50:881-887)

A thin liquid layer of metallic mercury $(\mathrm{Hg})$ is used as a cathode in the $\mathrm{Hg}$ based chloralkali industry to electrolyse brine. Chlorine, caustic soda, and

Department of Occupational Medicine, Telemark Central Hospital, N-3906 Porsgrunn, Norway

D G Ellingsen, $\mathrm{H}$ Kjuus

Department of Occupational Medicine, Sahlgrens University Hospital, S-412 66 Gøteborg, Sweden

L Barregård

Department of Immunology, National Institute of Public Health, N-0462 Oslo, Norway

P I Gaarder

Department of Clinical Chemistry, University Hospital, S-221 85 Lund, Sweden

B Hultberg hydrogen are the main products from the process. Hence, exposure to chlorine and $\mathrm{Hg}$ vapour are potential hazards to the workers' health. A minor exposure to dusts of $\mathrm{Hg}$-chlorine reaction products may also occur. ${ }^{1}$

Inorganic $\mathrm{Hg}$ compounds may cause renal damage among exposed subjects. ${ }^{23}$ Case reports of glomerulonephritis and nephrotic syndrome have been presented, ${ }^{45}$ and an increased prevalence of proteinuria $^{6-9}$ has been found in cross sectional studies among exposed workers. Other authors have reported increased enzymuria indicating an effect on the renal tubules. ${ }^{10-13}$ The reported effects have generally been small and the clinical significance of the findings is unclear.

Patients treated with $\mathrm{Hg}$ compounds may develop glomerulonephritis, which is usually of the immune complex type. ${ }^{14}$ Studies carried out in rats have shown that $\mathrm{HgCl}_{2}$ can induce a glomerulonephritis, characterised initially by autoantibodies to the glomerular basement membrane (a-GBMs), changing later to an immune complex type nephritis. ${ }^{15-17}$ An increased prevalence of circulating aGBMs of the antilaminin variety has been reported in male workers exposed to $\mathrm{Hg}$ vapour. ${ }^{18}$

Barregård et $a l^{10}$ did not find any decrease in urinary $\mathrm{N}$-acetyl- $\beta-\mathrm{D}$-glucosaminidase activity (U-NAG) among 15 chloralkali workers after an exposure free interval of 20 days. To our knowledge this is the only study concerning the reversibility of renal effects after cessation of exposure to $\mathrm{Hg}$ vapour.

The aim of the present study was to investigate the possible renal effects of previous exposure to $\mathrm{Hg}$ vapour among former chloralkali workers. Indicators of renal dysfunction were U-alb, U-NAG, and NAG, and the activities of NAG A (U-NAG A) and NAG B (U-NAG B) in a highly exposed subgroup. Also, a-GBMs in serum were determined.

The plant under investigation closed in 1987. This cross sectional study was carried out during 11 months of 1989 as a part of a comprehensive study on possible adverse health effects resulting from exposure to mercury vapour among former chloralkali workers. 


\section{Material and methods}

SUBJECTS

Details regarding the study design have been described elsewhere. ${ }^{19}$ In summary, all male workers under 65 years of age exposed to $\mathrm{Hg}$ vapour for at least one year at the plant under study, who had delivered samples for the determination of urinary $\mathrm{Hg}$ concentration ( $\mathrm{U}-\mathrm{Hg}$ ) in at least four quarters during their time of exposure, could be invited for participation. Of the 130 subjects who met these inclusion criteria, seven were dead, although none died because of renal diseases. Altogether 24 subjects were excluded, mainly due to solvent exposure $(n=9)$ or alcohol abuse $(n=6)$. No subjects were excluded due to renal diseases.

The participation rate was $82 \cdot 5 \%(n=77)$ among the exposed subjects. There were no known cases of renal disease among the non-responders, who had a mean exposure time of 8.1 years.

The reference group comprised randomly selected men employed in nitrate fertiliser production in the same company, frequency matched for age. The participation rate among the referents, who had never been exposed to $\mathrm{Hg}$ compounds at work, was $86 \cdot 3 \%(n=53)$.

The subjects under study have been described elsewhere. ${ }^{19}$ The mean age of the exposed subjects and referents was $44 \cdot 8$ (range $24 \cdot 2-64 \cdot 8$ ) years and $45 \cdot 8$ (range $24 \cdot 3-63 \cdot 7$ ) years respectively. The current $\mathrm{U}-\mathrm{Hg}$ was on average 1.8 (range $0 \cdot 3-6 \cdot 1$ ) $\mathrm{nmol} / \mathrm{mmol}$ creatinine and 1.3 (range $0.3-3 \cdot 8$ ) $\mathrm{nmol} / \mathrm{mmol}$ creatinine respectively, among the exposed subjects and referents, and the current blood $\mathrm{Hg}$ concentration $(\mathrm{B}-\mathrm{Hg}$ ) was 26.4 (range $12 \cdot 0-61 \cdot 0$ ) $\mathrm{nmol} / 1$ and $28 \cdot 3$ (range 15.0-64.0) $\mathrm{nmol} / \mathrm{l}$. The mean systolic and diastolic blood pressure was 146 (range 106-190) $\mathrm{mm} \mathrm{Hg}$ and 90 (range 65-115) $\mathrm{mg} \mathrm{Hg}$ among the exposed v 146 (range 120-195) $\mathrm{mm} \mathrm{Hg}$ and 91 (range 70-106) $\mathrm{mm} \mathrm{Hg}$ among the referents.

The mean time of exposure to $\mathrm{Hg}$ vapour was 7.9 (range $1 \cdot 1-36 \cdot 2$ ), years in the index group, and the exposure had ceased on average 12.3 (range $1-35)$ years before the study. Based on a long duration of exposure or high $\mathrm{U}-\mathrm{Hg}$ during the time of work, a subgroup $(n=30)$ among the highest exposed workers was selected for the determination of U-NAG A and U-NAG B. Their average duration of exposure was 11.5 years. These subjects were individually age matched $( \pm 1$ year) with 30 referents. The mean age was 47.8 (range 31.3-64.8) years among the exposed subjects and $47 \cdot 9$ (range $32 \cdot 0-63 \cdot 7$ ) years among the referents.

\section{ASSESSMENT OF EXPOSURE}

Details on the exposure to $\mathrm{Hg}$ and on the calculation of a cumulative $\mathrm{U}-\mathrm{Hg}$ "dose" have been reported elsewhere. ${ }^{19}$ In brief, biological monitoring of the workers by the determination of $\mathrm{U}-\mathrm{Hg}$ in morning urine samples commenced in 1948, one year after the start of production. The $\mathrm{U}-\mathrm{Hg}$ has been determined in more than 2300 samples among the 77 exposed study subjects. Based on these results, a cumulative U-Hg "dose" (cum U-Hg) was calculated for each exposed subject as the sum of the mean $\mathrm{U}-\mathrm{Hg}$ in each year of employment.

The U-Hgs were not adjusted for urinary dilution until 1979.

\section{EXAMINATION}

A detailed work history was obtained by interviewing each participant. A short clinical examination was carried out. Morning samples of urine were collected on two consecutive days and stored in NUNC $(10 \mathrm{ml})$ polypropylene tubes for the determination of U-NAG and U-alb. Venous blood samples were taken from the cubital vein. Serum samples for the determination of a-GBM were stored in NUNC tubes $(10 \mathrm{ml})$. All samples were stored at $-20^{\circ} \mathrm{C}$ until analysis.

\section{ANALYSES}

The sampling and analytical procedures for the determination of current $\mathrm{U}-\mathrm{Hg}$ and $\mathrm{B}-\mathrm{Hg}$ have been reported elsewhere. ${ }^{20}$

The total activity of $\beta$-hexosaminidase (EC $3 \cdot 2 \cdot 1 \cdot 30 ; \mathrm{NAG}$ ) in urine (U-NAG) was determined colorimetrically with $p$-nitro-phenyl-2-acetamido-2deoxy- $\beta$-D-glucopyranoside as the substrate. ${ }^{21} p$ Nitrophenol was used as the standard. One unit (U) of enzyme activity is defined as $1 \mu \mathrm{M}$ substrate hydrolysed per minute. For the assay of U-NAG A and U-NAG $B$, enzyme immunoassay (EIA) methods with specific monoclonal antibodies were used. ${ }^{22}$

The U-alb was determined by nephelometry (Behring nephelometer analyser) after adding specific antibodies to human albumin (Dakopatts rabbit anti-human albumin No $Q$ 328). Before the analysis of the thawed samples, $20 \mu \mathrm{l}$ of tween 20 was added to $1 \mathrm{ml}$ of urine and the samples were incubated at $37^{\circ} \mathrm{C}$ for two hours. Human serum protein standards were used for calibration. The coefficient of variation (CV) for analyses of the same samples on consecutive days, was $4 \cdot 8 \%$.

The test for a-GBM was carried out with an enzyme linked immunosorbent assay (ELISA). The ELISA test was performed with the anti-goodpasture antigen rapid kits from BioCarb Diagnostics $A B$, Lund, Sweden, from the manufacturer's instructions. Serum samples from both exposed subjects and referents were tested on each ELISA plate. The results are given as optical density (OD) $\times 1000$. Also, IgG antibodies to GBM were detected by indirect immunofluorescence on pronase treated frozen sections of human cadaveric kidney 
blood group 0, with serum diluted 1:2. Only IgG antibodies were tested for immunofluorescence. Serum samples that were positive at the screening dilution were titrated to their end points. The immunofluorescence methods have been described in detail previously. ${ }^{23}$

Due to the breakage of one tube containing serum, the a-GBMs were determined in 76 exposed subjects.

The urinary variables were determined on samples from two consecutive days to reduce the influence of the day to day variation in the urinary excretion of these compounds. The mean value of the two days was used in the analysis of the data. The urinary variables presented were corrected for urinary dilution, with urinary creatinine determined by the method of Jaffé.

\section{STATISTICS}

The distributions of U-alb, U-NAG, U-NAG A, UNAG B, and a-GBM were skewed. Consequently, non-parametric (Mann-Whitney) test statistics were used for the intergroup comparisons. Spearman's rank correlation was applied when assessing the univariate relations between untransformed variables. For assessing the magnitude of the storage effect and dose-response relations, univariate least square regression analysis was applied after $\log$ transforming the dependent variables. This was also the case for the multiple linear regression analysis. Log transformation was done to achieve homoscedasticity, and the procedure also normalised the distributions. The level of significance was set at $5 \%$ (two tailed).

The $\chi^{2}$ test was applied for categorical variables. The level of significance was set at 5\% (one tailed). The statistical calculations were performed on a personal computer with the statistical package BMDP PC-90.

\section{Results}

Table 1 presents the distribution of the yearly mean cum U-Hg among the exposed subjects related to the number of years exposed. Thirty nine subjects had a mean $\mathrm{U}-\mathrm{Hg}$ exceeding $400 \mathrm{nmol} \mathrm{Hg} / 1 /$ year. Eighty six per cent of the subjects $(n=66)$ had at least once had a U-Hg peak exceeding $500 \mathrm{nmol}$ $\mathrm{Hg} / 1$, whereas $36 \%(\mathrm{n}=28)$ exceeded $1500 \mathrm{nmol}$ $\mathrm{Hg} / 1$ at least once.

As the urine specimens were collected on two consecutive days, the relations between $U$-alb, U-NAG, U-NAG A, and U-NAG B excreted on the first day and the second day were assessed with Spearman's rank correlation on untransformed variables. The correlation coefficients were 0.71 (U-alb), 0.47 (U-NAG), 0.43 (U-NAG A), and 0.46 (U-NAG B) respectively. All correlation coef-
Table 1 Distribution of the annual mean urinary mercury concentration $(\mathrm{U}-\mathrm{Hg})$ related to number of years exposed among 77 chloralkali workers previously exposed to $\mathrm{Hg}$ vapour

\begin{tabular}{lccccc}
\hline $\begin{array}{l}\text { Mean } U-H g \\
\text { (nmol/l) }\end{array}$ & $1-2$ & $3-4$ & $5-9$ & $\geqslant 10$ & Total \\
\cline { 2 - 6 } & & & & & \\
$0-199$ & $1(1 \cdot 3)$ & $1(1 \cdot 3)$ & $9(11 \cdot 7)$ & $7(9 \cdot 1)$ & $18(23 \cdot 4)$ \\
$200-399$ & $2(2 \cdot 6)$ & $4(5 \cdot 2)$ & $6(7 \cdot 8)$ & $8(10 \cdot 4)$ & $20(26 \cdot 0)$ \\
$400-599$ & $1(1 \cdot 3)$ & $4(5 \cdot 2)$ & $6(7 \cdot 8)$ & $6(7 \cdot 8)$ & $17(22 \cdot 1)$ \\
$\geqslant 600$ & $15(19 \cdot 5)$ & $2(2 \cdot 6)$ & $3(3 \cdot 9)$ & $2(2 \cdot 6)$ & $22(28 \cdot 6)$ \\
Total & $19(24 \cdot 7)$ & $11(14 \cdot 3)$ & $24(31 \cdot 2)$ & $23(29 \cdot 9)$ & $77(100 \cdot 0)$ \\
\hline
\end{tabular}

ficients were statistically significant $(p<0.001)$.

The laboratory analyses were all performed after the collection of the biological samples was completed. The effect of storage time on the urinary variables was studied among all subjects in a least square linear regression analysis. No significant associations between storage time and $\mathrm{U}$-alb (log) or U-NAG B (log) were observed; however, the UNAG (log) and U-NAG A (log) correlated significantly with the storage time. The correlation coefficients (Pearson's) were $-0.21(p=0.02)$ and $-0.34(p<0.01)$ respectively. Spearman's rank correlation on untransformed variables did not change the correlation coefficients substantially (U-NAG; $\mathrm{r}=-0 \cdot 18, \mathrm{p}=0.04$, U-NAG A; $\mathrm{r}=-0 \cdot 43, \mathrm{p}<0 \cdot 001)$. The urine specimens used for the determination of U-NAG had on average been stored for 392 days, and the shortest storage time was 117 days before analysis. Hence, U-NAG and U-NAG A were adjusted (U-NAG ${ }_{\text {adi }}, U-N A G A_{\text {adj }}$ ) in relation to the urine specimen with the shortest storage time. The adjustments were based on the regression equation calculated in the least square regression analysis. No effect of storage time was found for a-GBM.

Table 2 presents U-NAG, U-NAG ${ }_{\text {adi }}, \mathrm{U}-\mathrm{alb}$, and

Table 2 Urinary albumin (U-alb) and $N$-acetyl- $\beta-D-$ glucosaminidase ( $U-N A G)$, and the concentration of antibodies to the glomerular basement membrane (a-GBM) in serum among 77 subjects previously exposed to $\mathrm{Hg}$ vapour and 53 referents

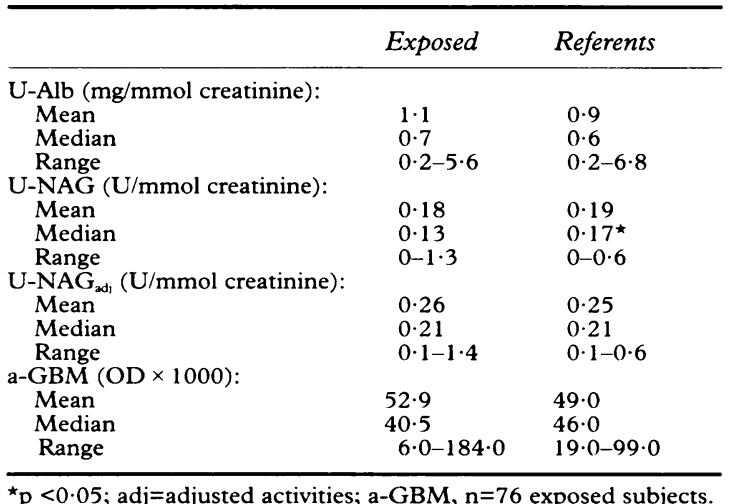


a-GBM among all exposed subjects and referents. The U-NAG was significantly higher among the referents compared with the exposed subjects $(p=0.047)$. The difference disappeared when adjusted U-NAGs were used. A statistically significant difference in the variance (Levene's test) of aGBM was found between the exposed subjects and referents, with CVs of $66 \%$ and $37 \%$ respectively. Weak antibodies to the glomerular basement membrane detected by indirect immunofluorescence were found in one exposed subject $v$ three referents (not significant, not tabulated).

Table 3 gives U-NAG A and U-NAG B among the 30 selected highly exposed subjects and 30 age matched referents. A non-significant higher activity of U-NAG A among the referents was found compared with the exposed subjects, but the difference disappeared when adjusting for storage time.

The 90th percentile among all subjects was selected as the cut off point when analysing the distribution of high $\mathrm{U}-\mathrm{alb}, \mathrm{U}-\mathrm{NAG}_{\mathrm{adj}}$, and a-GBM. Table 4 presents the results. For a-GBM and Ualb, a statistically significant higher prevalence of values exceeding the 90th percentile was found among the exposed subjects compared with the referents. Figure 1 presents the distribution of a-GBM among the exposed subjects and referents. Figure 2

Table 3 Age, exposure related variables, and the activity of urinary $N$-acetyl- $\beta-D$-glucosaminidase $A(U-N A G A)$ and $B(U-N A G B)$ among 30 selected high exposed subjects and 30 age matched referents

\begin{tabular}{|c|c|c|}
\hline & Exposed & Referents \\
\hline \multicolumn{3}{|l|}{ Age: } \\
\hline Mean & $47 \cdot 8$ & $47 \cdot 9$ \\
\hline Median & $46 \cdot 8$ & $47 \cdot 7$ \\
\hline Range & $31 \cdot 3-64 \cdot 8$ & $32 \cdot 0-63 \cdot 7$ \\
\hline \multicolumn{3}{|c|}{ Cum U-Hg (nmol/1): } \\
\hline Mean & 5736 & - \\
\hline Median & 4654 & - \\
\hline Range & $1979-17229$ & - \\
\hline \multicolumn{3}{|c|}{ Years exposed: } \\
\hline Mean & $11 \cdot 5$ & - \\
\hline Median & $10 \cdot 0$ & - \\
\hline Range & $1 \cdot 5-36 \cdot 2$ & - \\
\hline \multicolumn{3}{|c|}{ U-Hg (nmol/mmol creatine): } \\
\hline Mean & $2 \cdot 2$ & $1 \cdot 1$ \\
\hline Median & $1 \cdot 7$ & $1 \cdot 0^{\star \star}$ \\
\hline Range & $0 \cdot 5-6 \cdot 1$ & $0 \cdot 3-2 \cdot 5$ \\
\hline \multicolumn{3}{|c|}{$\mathrm{B}-\mathrm{Hg}(\mathrm{nmol} / \mathrm{l})$ : } \\
\hline Mean & $28 \cdot 3$ & $28 \cdot 5$ \\
\hline Median & $28 \cdot 0$ & $27 \cdot 0$ \\
\hline Range & $12 \cdot 0-61 \cdot 0$ & $17 \cdot 0-57 \cdot 0$ \\
\hline \multicolumn{3}{|c|}{ U-NAG A (U/mmol creatine): } \\
\hline Mean & $0 \cdot 16$ & $0 \cdot 21$ \\
\hline Median & 0.11 & $0 \cdot 20$ \\
\hline Range & $0-0.9$ & $0-0 \cdot 6$ \\
\hline \multicolumn{3}{|c|}{ U-NAG A $A_{3}(\mathrm{U} / \mathrm{mmol}$ creatine): } \\
\hline Mean & 0.35 & 0.35 \\
\hline Median & $0 \cdot 32$ & $0 \cdot 34$ \\
\hline Range & $0 \cdot 1-1 \cdot 0$ & $0 \cdot 2-0 \cdot 7$ \\
\hline \multicolumn{3}{|c|}{ U-NAG B (U/mmol creatine): } \\
\hline Mean & $0 \cdot 13$ & $0 \cdot 12$ \\
\hline Median & $0 \cdot 10$ & $0 \cdot 12$ \\
\hline Range & $0-0.5$ & $0-0 \cdot 3$ \\
\hline
\end{tabular}

${ }^{\star \star} \mathrm{p}<0.01 ;$ adj $=$ adjusted activities.
Table 4 Distribution of urinary albumin (U-Alb) and $N$-acetyl- $\beta$-D-glucosaminidase $\left(U-N A G_{a d j}\right)$ and antibodies to the glomerular basement membrane (a-GBM) exceeding the 90th percentile among 77 mercury exposed subjects and 53 referents

\begin{tabular}{lllll}
\hline & Cut off & Exposed & Referents $p$ Value \\
\hline U-Alb $_{\text {U-NAG }}$ & $2 \cdot 25$ (mg/mmol creatinine) & 11 & 2 & 0.04 \\
a-GBM & $0 \cdot 42$ (U/mmol creatinine) & 10 & 4 & $0 \cdot 25$ \\
a-GB (OD $\times 1000$ & 11 & 2 & 0.04 \\
\hline
\end{tabular}

The cut off for U-NAG included two measurements. a-GBM $\mathrm{n}=76$ exposed subjects.

presents the distribution of a-GBMs related to the number of years since cessation of exposure. Most of the higher concentrations were found among subjects in which exposure had ceased a short time before the study. The relation between a-GBM and time since cessation of exposure was not significant

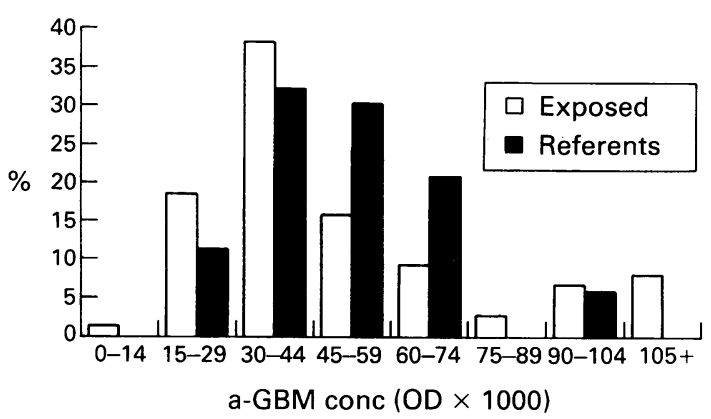

Figure 1 Distribution of the concentrations of antibodies to the glomerular basement membrane (a-GBM) measured among 76 chloralkali workers previously exposed to $\mathrm{Hg}$ vapour and 53 referents.

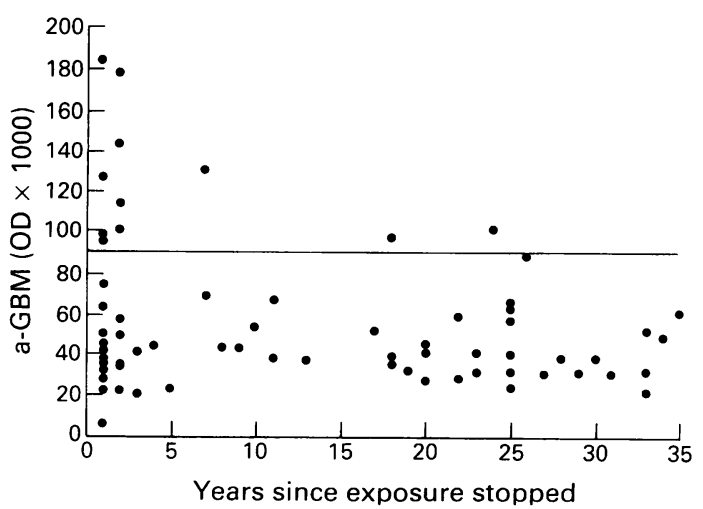

Figure 2 Concentrations of antibodies to the glomerular basement membrane ( $a-G B M$ ) related to number of years since last exposure among 76 chloralkali workers previously exposed to $\mathrm{Hg}$ vapour. The solid line marks the 90th percentile among all subjects under study. 
however, with Spearman's rank correlation $(r=-0 \cdot 14)$. The higher U-albs were not related to time since stopping exposure. The exposed subjects with the higher a-GBMs did not differ from the other exposed subjects with regard to current $\mathrm{B}-\mathrm{Hg}$ or $\mathrm{U}-\mathrm{Hg}$, exposure related variables (duration of exposure or cum $\mathrm{U}-\mathrm{Hg}$ ), nor to $\mathrm{U}$-alb and $\mathrm{U}-$ $\mathrm{NAG}_{\text {adj }}$. Exposed subjects exceeding the 90 th percentile for U-alb did not differ from the remaining exposed subjects with regard to the exposure related indices nor to a-GBM. They had significantly $(p=0.03)$ higher $\mathrm{U}-\mathrm{NAG}_{\mathrm{adj}}$ (mean 0.44 (range $0 \cdot 1-1.4) \mathrm{U} / \mathrm{mmol}$ creatinine) compared with the remaining exposed subjects (mean 0.22 (range $0 \cdot 1-0 \cdot 5) \mathrm{U} / \mathrm{mmol}$ creatinine).

Dose-response relations between exposure related indices and $\mathrm{U}$ alb $(\log ), \mathrm{U}-\mathrm{NAG}_{\mathrm{adj}}(\log )$, and aGBM $(\log )$ were studied in a least square linear regression analysis among the exposed subjects. Neither current $\mathrm{U}-\mathrm{Hg}$, current $\mathrm{B}-\mathrm{Hg}$, nor cum U$\mathrm{Hg}(\log )$ were significantly correlated with $\mathrm{U}-\mathrm{alb}$ $(\log )$ or a-GBM (log). Age (Pearson's $r=0.37$, $\mathrm{p}=0.001$ ) and cum U-Hg (log) (Pearson's $r=0.23$, $\mathrm{p}=0.04$ ) were significantly correlated with $U$ $\mathrm{NAG}_{\mathrm{adj}}(\log )$. Age and cum U-Hg (log) were subsequently used as independent variables in a multiple linear regression analysis to study both variables in the same model. Age was significantly included in the model $(p=0.01)$, whereas cum $\mathrm{U}-\mathrm{Hg}(\log )$ was not. Multiple R was 0.37 . The U-NAG adj $(\log )$ was also correlated with age among the referents (Pearson's $\mathrm{r}=0.32, \mathrm{p}=0.02$ ).

\section{Discussion}

The inclusion criteria for the study were met by 130 previously exposed subjects who were both with and without employment at the time of the investigation. The referents were selected among current employees in the nitrate fertiliser plant, which implies that a selection of generally healthier referents could have occurred. Only seven subjects in the index group were not in active work at the time of examination, and none were excluded due to renal diseases. Seven of the 130 eligible subjects were dead, none of them due to renal diseases. Thus it is not likely that this possible selection has biased the results of the study.

The laboratory that analysed the urine samples between 1948 and 1987 carried out a monthly quality control for most of the period comparing their results with those of external laboratories. Also, more than 2300 individual $\mathrm{U}-\mathrm{Hg}$ measurements known to the investigators among the 77 exposed subjects were used to estimate previous $\mathrm{Hg}$ exposure. Hence, it may be assumed that the estimates of cum $\mathrm{U}-\mathrm{Hg}$ are valid.

To reduce the day to day variation in the studied urinary indices, they were determined in samples from two consecutive days. The activity of all NAG indices showed a low correlation between the two days, indicating a substantial day to day variability, which has been reported by others. ${ }^{24}$ The intraindividual variation in U-NAG may reflect a real biological variation, but may also be due to the urinary environment.

The referents were selected later than the exposed subjects. When correcting for the different storage times, U-NAG was similar among the exposed subjects and the referents. An association was found between age and U-NAG, which has also been found by others. ${ }^{25}$ When corrected for age no relation was found between U-NAG and the exposure related indices in the present study.

Barregård et al $^{10}$ found increased U-NAG when $\mathrm{U}-\mathrm{Hg}$ exceeded $250 \mathrm{nmol} / \mathrm{l}$. The mean $\mathrm{U}-\mathrm{Hg}$ in the present study was $531 \mathrm{nmol} / \mathrm{l} / \mathrm{year}$, and 54 subjects had a mean U-Hg exceeding $250 \mathrm{nmol} / 1 / \mathrm{year}$, indicating that the examined subjects have been exposed to concentrations of $\mathrm{Hg}$ vapour exceeding the level where increased U-NAG has been found. These findings indicate that the increased U-NAG, as reported in previous studies among workers under ongoing exposure to $\mathrm{Hg},{ }^{10113}$ in most cases could be a reversible phenomenon. Due to the effect of storage on urinary NAG, however, firm conclusions cannot be drawn. The U-NAG A and U-NAG B did not differ significantly between the two groups under study. To our knowledge, these NAG isoenzymes have not been studied previously among subjects exposed to $\mathrm{Hg}$ vapour.

The U-alb was generally low among the participants of the study. A non-significant raised U-alb among the exposed subjects was found, compared with the referents. The prevalence of concentrations exceeding the 90th percentile was also higher among the exposed workers. No relation was found, however, between exposure or time related indices and U-alb. Hence, the results from the present study are in accordance with the view that increased albuminuria among workers under ongoing exposure to $\mathrm{Hg}$ vapour ${ }^{68}$ will at least in most cases normalise after stopping exposure.

The concentration of circulating a-GBM in serum among the exposed subjects was not significantly different from that of the referents. The variance differed significantly, however. The raised prevalence of a-GBM exceeding the 90th percentile were mainly found among the subjects where the exposure had ceased a short time before the examination. This could suggest an immunological response resulting from exposure to $\mathrm{Hg}$ vapour, which could be reversible. None of the subjects had a positive a-GBM test, however, according to the cut off value suggested by the manufacturer of the kits. Further, there was no increased prevalence of 
a-GBM, as determined by indirect immunofluorescence, among exposed subjects compared with the referents.

Experimental studies in animals have shown immunologically mediated glomerulonephritis after exposure to $\mathrm{Hg}^{16}$ Mercuric chloride has been shown to induce a-GBM in the Brown-Norway rat. ${ }^{17}$ The antibodies deposit along the GBMs in the kidneys. ${ }^{26}$ The antibody titre has been shown to decrease spontaneously after a few weeks, even with continued $\mathrm{HgCl}_{2}$ injections. ${ }^{16}$ Later on in the process, circulating immune complexes also appear. ${ }^{26}$

Two workers exposed to $\mathrm{Hg}$ at a chemical plant developed nephrotic syndrome due to membranous glomerulonephritis. ${ }^{5}$ Confluent finely granular epimembranous deposits of IgG and C3 were shown by immunohistochemical studies. This may indicate immune complex deposition rather than bound a-GBM. One of the patients experienced a clinical remission, the other had persistent proteinuria after 20 months. Lauwerys et $a l^{18}$ found an a-GBM of antilaminin specificity in eight out of 62 male workers exposed to $\mathrm{Hg}$ vapour, without finding associations with any of several indices of kidney function. This finding was not reproduced by Bernard et al. ${ }^{28}$ Langworth et al ${ }^{29}$ found low titres of a-GBM and antilaminin antibodies among chloralkali workers exposed to low concentrations of $\mathrm{Hg}$. Lauwerys et al ${ }^{30}$ point out that the possible value of monitoring the presence of a-GBM in serum samples from workers exposed to nephrotoxic chemicals has not yet been clarified. The a-GBM as determined by the ELISA kits used in the present study are directed against the M2 subunit of the globular domain of collagen IV, ${ }^{31}$ and are thus different from the antilaminin variety.

In summary, no increased U-NAG, U-NAG A, and U-NAG $B$ were found among former chloralkali workers compared with the referents; nor was the U-alb raised. An increased prevalence of raised a-GBM was found among subjects for whom the exposure had ceased shortly before the study. The clinical importance of this is not clear, but the possibility of an immunological activation might be worth evaluating in future studies.

We thank Mrs Herbjørg Schistad and Mrs Liv Brun for technical assistance, Ms Patricia Flor for her linguistic assistance, and Yngvar Thomassen, MSc for the determination of current urinary and blood mercury concentrations. The study was carried out with financial support from Norsk Hydro A/S, Norway.

Requests for reprints to: Dag G Ellingsen, Department of Occupational Medicine, Telemark Central Hospital, N-3906 Porsgrunn, Norway.
1 Menke $\mathrm{R}$, Wallis G. Detection of mercury in air in the presence of chlorine and water vapor. Am Ind Hyg Assoc $\mathcal{F}$ 1980;41:120-4.

2 Berlin M. Mercury. In Friberg L, Nordberg GF, Vouk VB, (eds). Handbook on the toxicology of metals, 2nd ed. Vol 2. Amsterdam: Elsevier, 1986;387-445.

3 World Health Organization. Environmental Health Criteria 118. Inorganic mercury. Geneva: WHO, 1991.

4 Kazantzis G, Schiller KFR, Asscher AW, Drew RG. Albuminuria and the nephrotic syndrome following exposure to mercury and its compounds. $Q \mathcal{F ~ M e d ~ 1 9 6 2 ; 3 1 : 4 0 3 - 1 8 . ~}$

5 Tubbs RR, Gephardt GN, McMahon JT, et al. Membranous glomerulonephritis associated with industrial mercury exposure. Am f Clin Pathol 1982;77:409-13.

6 Buchet JP, Roels H, Bernard A, Lauwerys R. Assessment of renal function of workers exposed to inorganic lead, cadmium and mercury vapor. f Occup Med 1980;22:741-50.

7 Foa V, Caimi L, Amante L, et al. Patterns of some lysosomal enzymes in the plasma and of proteins in urine of workers exposed to inorganic mercury. Int Arch Occup Environ Health 1976;37:115-24.

8 Roels H, Lauwerys R, Buchet JP, et al. Comparison of renal function and psychomotor performance in workers exposed to elemental mercury. Int Arch Occup Environ Health 1982;50:77-93.

9 Schaller KH, Gonzales J, Thürauf J, Schiele R. Früher-kennung von Nierenschäden bei beruflich gegenuber Blei, Quecksilber und Cadmium exponierten Personen. Zentralblatt fur Bakteriologie [Orig B] 1980;171:320-35.

10 Barregård L, Hultberg B, Schütz A, Sällsten G. Enzymuria in workers exposed to inorganic mercury. Int Arch Occup Environ Health 1988;61:65-9.

11 Ehrenberg RL, Vogt RL, Smith AB, et al. Effects of elemental mercury exposure at a thermometer plant. Am $f$ Ind Med 1991;19:495-507.

12 Roels H, Gennart JP, Lauwerys R, Buchet JP, Malchaire J, Bernard A. Surveillance of workers exposed to mercury vapour: validation of a previously proposed biological threshold limit value for mercury concentration in urine. $A m \mathcal{F}$ Ind Med 1985;7:45-71.

13 Stonard MD, Chater BV, Duffield DP, Nevitt AL, O'Sullivan JJ, Steel GT. An evaluation of renal function in workers occupationally exposed to mercury vapor. Int Arch Occup Environ Health 1983;52:177-89.

14 Bernard A, Lauwerys R. Epidemiological application of early markers of nephrotoxicity. Toxicol Lett 1989;46:293-306.

15 Druet P, Bernard A, Hirsch F, et al. Immunologically mediated glomerulonephritis induced by heavy metals. Arch Toxicol 1982;50:187-94.

16 Pelletier L, Hirsch F, Rossert J, Druet E, Druet P. Experimental mercury-induced glomerulonephritis. Springer Semin Immunopathol 1987;9:359-69.

17 Sapin C, Druet E, Druet P. Induction of anti-glomerular basement membrane antibodies in the Brown-Norway rat by mercuric chloride. Clin Exp Immunol 1977;28:173-9.

18 Lauwerys R, Bernard A, Roels H, et al. Anti-laminin antibodies in workers exposed to mercury vapour. Toxicol Lett 1983;17:113-6.

19 Ellingsen DG, Mørland T, Andersen A, Kjuus H. Relation between exposure related indices and neurological and neurophysiological effects among workers previously exposed to mercury vapour. Br $\mathcal{F}$ Ind Med 1993;50:736-44.

20 Ellingsen DG, Holland RI, Thomassen Y, Olstad ML, Frech $\mathbf{W}$, Kjuus $\mathrm{H}$. Mercury and selenium in workers previously exposed to mercury vapour at a chloralkali plant. $B r \mathcal{F}$ Ind Med 1993;50:745-52.

21 Hultberg B, Wieslander J. Urinary excretion of $\beta$-hexosaminidase in patients with vesico-ureteric reflux. Acta Med Scand 1982;211:257-9.

22 Hultberg B, Isaksson A. Enzyme immunoassay of $\beta$-hexosaminidase isoenzymes in human urine and renal cortex with monoclonal antibodies. Enzyme 1989;42:25-30.

23 Gaarder PI, Heier HE. A human autoantibody to renal collecting duct cells associated with thyroid and gastric autoimmunity and possibly renal tubular acidosis. Clin Exp Immunol 1983;51:29-37.

24 Agardh CD, Tallroth G, Hultberg B. Urinary N-acetyl- $\beta-D$ glucosaminidase activity does not predict development of diabetic nephropathy. Diabetes Care 1987;10:604-6.

25 Hultberg B, Isaksson A, Berg B, Tryding N, Ekman S, Nilsson JE. The effect of age and sex on $\beta$-hexosaminidase in urine. Clin Chim Acta 1988;177:271-4.

26 Druet P, Druet E, Potdevin F, Sapin C. Immune type 
glomerulonephritis induced by $\mathrm{HgCl}_{2}$ in the Brown Norway rat. Annales d'Immunologie 1978;129C:777-92.

27 Fukatsu A, Brentjens J, Killen P, Kleinman H, Martin G, Andres G. Glomerular immune deposits in rats injected with mercuric chloride $\left(\mathrm{HgCl}_{2}\right)$. Kidney Int 1987;31:320.

28 Bernard AM, Roels HR, Foidart JM, Lauwerys RL. Search for anti-laminin antibodies in the serum of workers exposed to cadmium, mercury vapour or lead. Int Arch Occup Environ Health 1987;59:303-9.

29 Langworth S, Elinder CG, Sundquist KG, Vesterberg O. Renal and immunological effects of occupational exposure to inorganic mercury. BrF Ind Med 1992;49:394-401.
30 Lauwerys R, Bernard A. Preclinical detection of nephrotoxicity: description of the tests and appraisal of their health significance. Toxicol Lett 1989;46:13-29.

31 Butkowski RJ, Wieslander J, Wisdom BJ, Barr JF, Noelken ME, Hudson BG. Properties of the globular domain of type IV collagen and its relationship to the Goodpasture antigen. f Biol Chem 1985;260:3739-47.

Accepted 21 December 1992

\section{Correspondence and editorials}

The British fournal of Industrial Medicine welcomes correspondence relating to any of the material appearing in the journal. Results from preliminary or small scale studies may also be published in the correspondence column if this seems appropriate. Letters should be not more than 500 words in length and contain a minimum of references. Table and figures should be kept to an absolute minimum. Letters are accepted on the understanding that they may be subject to editorial revision and shortening.

The journal now also publishes editorials which are normally specially commissioned. The Editor welcomes suggestions regarding suitable topics; those wishing to submit an editorial, however, should do so only after discussion with the Editor. 